\title{
Engineering Students' Language Learning Strategies (LLS) and Their Motivation in Learning Speaking Skills
}

Katherine Livan Kehing, Mohamad Sobri Suhaili, Radmila Ronios Mara, Alexander Andrew Kana, Diana Anak Ipan, Claudia Christy Blaise, Harwati Hashim

To Link this Article: http://dx.doi.org/10.6007/IJARBSS/v11-i6/10034

DOI:10.6007/IJARBSS/v11-i6/10034

Received: 13 April 2021, Revised: 15 May 2021, Accepted: 28 May 2021

Published Online: 18 June 2021

In-Text Citation: (Kehing et al., 2021)

To Cite this Article: Kehing, K. L., Suhaili, M. S., Mara, R. R., Kana, A. A., Ipan, D. A., Blaise, C. C., \& Hashim, H. (2021). Engineering Students' Language Learning Strategies (LLS) and Their Motivation in Learning Speaking Skills. International Journal of Academic Research in Business and Social Sciences, 11(6), 756770.

Copyright: (c) 2021 The Author(s)

Published by Human Resource Management Academic Research Society (www.hrmars.com) This article is published under the Creative Commons Attribution (CC BY 4.0) license. Anyone may reproduce, distribute, translate and create derivative works of this article (for both commercial and non-commercial purposes), subject to full attribution to the original publication and authors. The full terms of this license may be seen at: http://creativecommons.org/licences/by/4.0/legalcode

Vol. 11, No. 6, 2021, Pg. 756- 770

Full Terms \& Conditions of access and use can be found at http://hrmars.com/index.php/pages/detail/publication-ethics 


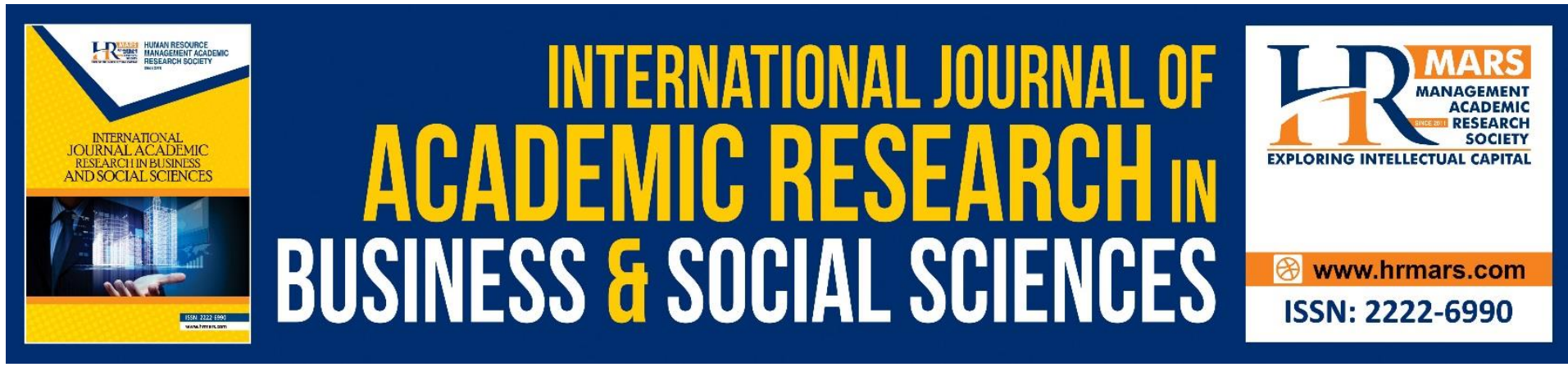

\title{
Engineering Students' Language Learning Strategies (LLS) and Their Motivation in Learning Speaking Skills
}

\author{
Katherine Livan Kehing ${ }^{1}{ }^{2}$, Mohamad Sobri Suhaili , ${ }^{2}$, Radmila \\ Ronios Mara¹, Alexander Andrew Kana1, Diana Anak Ipan¹, \\ Claudia Christy Blaise ${ }^{1}$, Harwati Hashim ${ }^{1}$ \\ ${ }^{1}$ Faculty of Education, Universiti Kebangsaan Malaysia, ${ }^{2}$ General Studies Department, \\ Politeknik Mukah, Sarawak \\ Email: kathlivan@pmu.edu.my
}

\begin{abstract}
One of the most important skills for an individual to learn is speaking skills. In preparation to enter the job market, students should be able to communicate effectively. There is a need to identify the language learning strategies used by good learners in learning speaking skills. Therefore, the objective of this study is to investigate the language learning strategies (LLS) in learning speaking skills and the motivation level to learn speaking by the Semester 1 engineering Diploma students in a polytechnic in Sarawak. A quantitative research was carried out. The purposive sampling method was used in selecting the respondents. Based on the findings, metacognitive strategies were the most used LLS while social strategies were the least used LLS. Learners' motivation level was average with low self-esteem as one of the factors that influenced the learning of speaking skills. More studies should be conducted to study the factors affecting the use of LLS among students for the exact purpose of understanding their way of learning a language. Students should also be aware of how to use LLS in learning speaking to develop their speaking abilities.
\end{abstract}

Keywords: Language Learning Strategies (LLS), Engineering, Diploma, Speaking Skills, Strategy Inventory for Language Learning (SILL)

\section{Introduction}

Speaking skill is an important skill for engineering students to acquire before they graduate with the purpose of being able to communicate effectively in their career's life as an engineer. Therefore, English plays an essential role in the engineering field as it is an international language spoken widely all over the world. Rao (2019) emphasized that learners need to acquire communication skills in English to enable them to be successful in their respective fields. Thus, there is a need for engineering students to acquire good speaking skills in English because most information and knowledge related to engineering is presented in English. According to Shrestha et al. (2016), engineering students, regardless of subject or faculty, need to have a strong command of the English language in order to understand and 
learn information from academic works. Besides that, it is also crucial for engineering students to be able to communicate well in English in the engineering field as it provides job opportunities globally. According to Shrestha et al. (2016), there is no guarantee that an engineering candidate who did well during their academic career, will perform well in their jobs without having a good level of proficiency in communication in English.

Apart from receiving guidance from language educators during their schooling years, engineering students need to find their own best ways to effectively learn speaking consciously or unconsciously as well as polishing their speaking skills. Despite receiving almost similar guidance from their language educators in learning English during their schooling years, it is somehow interesting that some students are able to master the language better and faster than their peers. Therefore, language learning strategies (LLS) plays a crucial role among student when learning speaking.

LSS had sparked the interest from educators and researchers and knowledge related to this matter has developed since the mid-1970s which pioneered by Rubin and Stern in 1975. Educators and researchers have not only paid attention on how language is taught but how it is learnt as well. The focus has moved from teaching to learning. The matter that concerns educators and researchers here is what Vrettou (2014) described as certain learners appeared to have some sort of abilities which contribute to their success in acquiring a language whereas other learners lacked these abilities. Thus, LSS has changed the role of the teacher in the class from playing a dominant role in the lesson but to become a guide or a facilitator to the learners and the focus is the learner and the learning, which specifically refers to how the learners acquire the language in their own ways.

This study investigates the LLS used by Semester 1 engineering Diploma students in a polytechnic in Sarawak to learn speaking, and their motivation level to learn speaking. The findings from this study will provide important information to researchers on how these students use LLS in learning speaking, and also will give a better view to researchers on how to expose LLS to the engineering students to help them improve their speaking skills more efficiently in which Hapsari (2019) stated that the teacher's knowledge of LSS will assist language learners to overcome their difficulties of their learning process.

\section{Research Objectives}

- To investigate the language learning strategies (LLS) used by Semester 1 engineering Diploma students in a polytechnic in Sarawak in learning speaking skills.

- To investigate the motivation level of Semester 1 engineering Diploma students in a polytechnic in Sarawak in using the language learning strategies to learn speaking.

\section{Literature Review}

Language Learning Strategies (LSS) has triggered the interest of many researchers around the world to produce more scholarly works on this matter. Researchers have done their research that focus on how the learners process new information and what techniques they use to comprehend, read, and recall knowledge acquired in the area of second or foreign language acquisition (Chien, 2010). A brief explanation of Language Learning Strategies (LLS) and how it is used in encouraging the learners to learn speaking skills are discussed in the following sections. 


\section{Language Learning Strategies (LLS)}

The goal of language learning, according to Hapsani (2019), is to achieve communicative competence, and as a result, understanding of the value of LLS for both educators and learners has grown since Rubin and Stern began their research on LLS in 1975, more and more scholarly works on LLS have been published.

Various researchers have given LLS various meanings. Wenden (1978a) identified LLS in terms of learning habits, such as learning and adapting the sense of a second or foreign language, cognitive theory, such as learners' strategic awareness of language learning, and affective theory, such as learners' motivation, attitude, and others, according to Chien (2010) and Hardan (2013). Language learning strategies, according to Chien (2010) and Hardan (2013), are activities, measures, or techniques that language learners use to promote language learning, as described by Rubin (1987).

There are two main categories of LLS; direct and indirect strategies which are also subdivided into six classes. In direct strategies, it includes memory strategies, cognitive strategies, and compensation strategies. These strategies involve in mental processing that requires the students to develop the skills of learning towards what they have learned. Meanwhile, for indirect strategies, it has been divided into metacognitive strategies, affective strategies and social strategies that provide indirect support for language learning by employing different strategies like focusing, arranging, evaluating, seeking opportunities, and lowering anxiety. As highlighted by Zare (2012) cited from Oxford (1990), indirect strategies enable the students to think at the higher level of thinking skills and grab the opportunities to try to react during the process of learning.

After all, to apply all the strategies mentioned above, students should have the sense of wanting to become a good language learner. Tigarajan et al. (2016) pointed out that a good language learner is described as someone who uses effective language learning strategies to achieve language learning success. The students have the desire to take the responsibility to learn by their own, gaining information, and keep practicing themselves to speak the English language. They must be confident if they want to learn because their confidence level will lead to a better communication that allows them to express themselves and communicate with others. Their confidence level may become one tool that open their minds to fresh ideas, unlock doors to new possibilities, and open windows to the world (Mahmood, 2014).

\section{Speaking Skills}

The aim of learning a language is to be able to communicate with others. It is necessary to develop strong communication skills in order to communicate with others by sharing ideas and providing input. Thus, speaking skill is the most important skill to acquire as it is an important method of communication. Rao (2019) stated that speaking skill become the most essential language skill among the four language skills to enable people to have good communication. Brown and Yoke (1983) as cited in Rao (2019) stated that the real test of speaking skill is when students use in real life situations.

Speaking is described as an interactive practice of forming meaning that involves generating, accepting, and processing information, according to Shiamaa (2006), who cited Burns and Joyce (1997). The sense in which it happens, the participants, and the intentions of speaking all influence its form and meaning. Everyone is well-informed that English nowadays is used worldwide. The education requires students to master the language and have a good speaking skill as it is a gateway for them to get a better job out there in the future. Good 
speaking skill will lead the students to become a good speaker or communicator when they can speak the English language well.

The main thing the students should have is motivation (Asif et al., 2019). According to Lai (2011), motivation refers to the motivations for behavior that are marked by willingness and volition. Thus, students who have motivation in themselves are willing to learn and practice to speak until they feel they are free from the difficulty zone of learning to speak (Asif et al., 2019). They will be at ease in communicating with other people using the English language without being afraid of making mistakes. This is how the good learners usually do for the sake of becoming a good English speaker. They can become very confident when speaking because they are already motivated (Asif et al., 2019). Without argument, it is believed that motivation has appeared to be the most important factor in the use of LLS in learning speaking skill (Bayuong et al., 2019; Rahimi et al., 2004).

\section{Motivation}

According to Lai (2011), motivation is the reason behind actions demonstrating enthusiasm and desire. Gredler et al. (2004) as cited in Lai (2011) described motivation as the power that trigger us to do or not do something. Motivation is a vital part in learning. It will determine the level of performance of the learners where educational psychologist acknowledged the role of motivation to support learner learning as vital (Lai, 2011). In the 21st century, motivation is crucial as part of life and career skills to prepare students for higher learning institutions and the working life (Lai, 2011).

Motivation can be classified into two categories which are intrinsic motivation and extrinsic motivation. Lai (2011) defined intrinsic motivation as something represented by individual satisfaction, interest, or desire. Intrinsic motivation aims to meet personal needs by doing things because we enjoy them instead of having to do things. In contrast, Lai (2011) defined extrinsic motivation as initiative controlled by reinforcement contingencies. Extrinsic motivation is the initiative to do something for some intended outcome.

\section{Strategy Inventory for Language Learning (SILL)}

In 1989, Rebecca Oxford developed a method to identify the types of strategies learners tend to employ to learn language known as Strategy Inventory for Language Learning (SILL). SILL is a useful instrument for educators to understand how learners learn language. SILL is a reference for language teachers on strategies their language learners employ to learn language.

SILL, according to Park (2011), consists of two types of learning strategies: direct and indirect learning strategies, depending on the level of technique item used in language learning. Direct strategies consist of "memory strategies, cognitive strategy and compensation strategies while indirect strategies consist of metacognitive strategies, affective strategies and social strategies".

SILL plays a vital role to give information that language educators need on how their learners learn language. This information will also give the language educators a better understanding of how to facilitate their language learners to learn language more successfully. In the EFL context's viewpoint from English language teachers, Hapsari (2013) as cited in Hapsari (2019) stated that non-native speaker teachers of English have better strategic competence in comparison to native speaker teachers because non-native speaker teachers of English have two advantages which are knowledge of the language structure of their own native language and English as the target language. This will be an advantage for 
learners as language educators have the capacity to perform code switching and code mixing to explain the target language (Hapsari, 2013 as cited in Hapsari, 2019).

\section{Methodology \\ Research Design}

A quantitative method was applied in this study. A questionnaire was distributed to the respondents.

\section{Population and Samples}

This research aims to identify the language learning strategies and the motivation level of Semester 1 engineering Diploma students in a polytechnic in Sarawak in learning speaking skills. The Semester 1 students are of 18 to 21 years old from Sabah, Sarawak and the Peninsular. They are from the Civil Engineering, Electrical Engineering and Mechanical Engineering Department.

Samples are selected based on the purposive sampling method. A total of 150 respondents were targeted for the questionnaire. However, only 107 responses were received. Since the questionnaire was distributed while the students were under the Enhanced Movement Control Order (EMCO) due to the Covid-19 pandemic, some students were under quarantine and were unable to get good internet connection to respond to the questionnaire.

\section{Research Instrument}

The research instrument was adapted from the Language Strategy Use Survey by Andrew D. Cohen, Rebecca L. Oxford and Julie C. Chi (2002). Only 18 items from speaking strategy use were adapted for the study since the researchers focused on speaking skills.

\section{Data Collection Procedure}

A questionnaire was distributed though Google Form. Google Form was used as it is the easiest way to collect information from the respondents who were undergoing online learning in campus. The link to the questionnaire was distributed through respective class teachers to be forwarded to the students.

\section{Data Analysis Method}

The information was gathered to learn about the engineering students' learning strategies for speaking skills. The distribution of quantitative data questionnaire was done online at the convenience of the respondents, and completed questionnaires were directly received once the respondents clicked on the link given. Respondents were given three (3) days to answer the questionnaire. Data from the questionnaires were gathered and presented in a computed frequency form to see the mean of each strategy.

\section{Findings}

The followings are the results which are organised based on the objectives of this study. The first section of the results discussed the demographic statistics of the respondents followed by learning strategies used by learners in learning speaking skills, while the last section focused on the motivation in learning speaking skills. 
INTERNATIONAL JOURNAL OF ACADEMIC RESEARCH IN BUSINESS AND SOCIAL SCIENCES Vol. 11, No. 6, 2021, E-ISSN: 2222-6990 @ 2021 HRMARS

\begin{tabular}{|c|c|c|c|c|}
\hline \multicolumn{5}{|c|}{ Demographic Characteristics } \\
\hline \multicolumn{2}{|l|}{ Gender } & Frequency & Percent \% & Valid Percent \% \\
\hline \multirow[t]{4}{*}{ Valid } & Missing & 1 & .9 & .9 \\
\hline & Male & 68 & 63.0 & 63.0 \\
\hline & Female & 39 & 36.1 & 36.1 \\
\hline & Total & 108 & 100.0 & 100.0 \\
\hline \multicolumn{5}{|l|}{ Age } \\
\hline \multirow[t]{5}{*}{ Valid } & 18 & 10 & 9.3 & 9.3 \\
\hline & 19 & 85 & 78.7 & 79.4 \\
\hline & 20 & 2 & 1.9 & 1.9 \\
\hline & 21 and above & 10 & 9.2 & 9.3 \\
\hline & Total & 107 & 99.1 & 100.0 \\
\hline \multicolumn{2}{|l|}{ Missing } & 1 & .9 & \\
\hline \multicolumn{2}{|c|}{ Total } & 108 & 100.0 & 100.0 \\
\hline \multicolumn{5}{|c|}{ Programme } \\
\hline \multirow[t]{5}{*}{ Valid } & Missing & 1 & .9 & .9 \\
\hline & Dip in Mechanical Eng. & 28 & 25.9 & 25.9 \\
\hline & Dip in Civil Eng. & 63 & 58.3 & 58.3 \\
\hline & $\begin{array}{l}\text { Dip in Electrical \& } \\
\text { Electronic Eng. }\end{array}$ & 16 & 14.8 & 14.8 \\
\hline & Total & 108 & 100.0 & 100.0 \\
\hline
\end{tabular}

Table 1: The Demographic Characteristics ( $n=108)$

Table 1 shows that male students dominated the survey with $63 \%$ compared to female with $36.1 \%$. This shows that most engineering students are male. One missing data was identified which makes the total number of respondents of 107 . Most of the participants were 19 years old with $78.7 \%$, followed by 18 years old at $9.3 \%, 21$ and above at $9.2 \%$ and 20 years old at $1.9 \%$. Most of the students who participated in this study were students from the Civil Engineering Department with 58.3\%, followed by the Mechanical Engineering Department with $25.9 \%$ and the Electrical Engineering Department, which consisted of $14.8 \%$ out of all the students.

\section{Language learning strategies (LLS) used by Semester 1 engineering Diploma students in a} polytechnic in Sarawak in learning speaking skills.

The first research question aims at studying how engineering students learn speaking skills. Therefore, the questionnaire used is adapted from Cohen et al. (2002) where only eighteen (18) items related to learning speaking skills are used and included in the questionnaire. These 18 questions are clustered based on the type of learning strategies they represented as illustrated in the following table: 


\begin{tabular}{ll}
\hline Memory Strategies & Item 1 \\
& Item 13 \\
\hline Cognitive Strategies & Item 2 \\
& Item 8 \\
& Item 10 \\
& Item 14 \\
\hline Compensation Strategies & Item 5 \\
& Item 6 \\
& Item 15 \\
& Item 16 \\
& Item 18 \\
\hline Metacognitive Strategies & Item 3 \\
& Item 7 \\
\hline Affective Strategies & Item 12 \\
\hline Social Strategies & Item 4 \\
& Item 11 \\
\hline
\end{tabular}

Table 2: Representation of the types of learning strategies in the questionnaire

The analysis done in the following table shows mean scores and its standard deviations based on the respondents' strategies in learning English language speaking skills. Overall data shows that the most preferable learning strategies used by Semester 1 engineering students are metacognitive strategies with the highest total mean of 3.90 and the highest median score of 3.50 making it the highest preferable strategies as compared to other strategies which median scores only ranges between 3.00 to 3.17. Metacognitive strategies are among three learning strategies under indirect strategies based on the Taxonomies of Language Learning Strategies (Oxford, 1990).

\begin{tabular}{|c|c|c|c|c|}
\hline & & & Statistic & Std. Error \\
\hline \multirow[t]{14}{*}{ Metacognitive } & Mean & & 3.3019 & .06020 \\
\hline & \multirow{2}{*}{$\begin{array}{l}\text { 95\% Confidence Interval for } \\
\text { Mean }\end{array}$} & Lower Bound & 3.1825 & \\
\hline & & Upper Bound & 3.4213 & \\
\hline & 5\% Trimmed Mean & & 3.3459 & \\
\hline & Median & & 3.5000 & \\
\hline & Variance & & .384 & \\
\hline & Std. Deviation & & .61983 & \\
\hline & Minimum & & 1.00 & \\
\hline & Maximum & & 4.00 & \\
\hline & Range & & 3.00 & \\
\hline & Interquartile Range & & 1.00 & \\
\hline & Skewness & & -.732 & .235 \\
\hline & Kurtosis & & .652 & .465 \\
\hline & Kurtosis & & -.285 & .465 \\
\hline
\end{tabular}

Table 3: Metacognitive strategies' scores 
Most respondents would agree to the two statements that represent the metacognitive strategies which are 1) plan out in advance what I want to say, and 2) Think about how a native speaker might say something and practice saying it that way. Both scored a mean of 3.42 and 3.15 respectively making them the most preferable strategies under metacognitive strategies. These two strategies are among favorite strategies where most respondents chose :1) I use this strategy and like it and 2) I have tried this strategy and would use it again. The statements proved that the respondents are very concern of their language whenever they are using it. Planning what to say and practice to say the way native speaker does are two strategies under metacognitive strategies where learners are thinking aloud and doing self-reflection to themselves.

Metacognitive Strategies

\begin{tabular}{lr|r|c} 
Item & $\mathrm{N}$ & Mean & $\begin{array}{c}\text { Std. } \\
\text { Deviati } \\
\text { on }\end{array}$ \\
\hline plan out in advance what I want to say & 106 & 3.15 & 0.826 \\
\hline $\begin{array}{l}\text { Think about how a native speaker } \\
\text { might say something and practice }\end{array}$ & 107 & 3.42 & 0.753 \\
$\begin{array}{l}\text { saying it that way } \\
\text { TOTAL }\end{array}$ & & \\
\hline
\end{tabular}

Table 4: Metacognitive strategies' mean and standard deviation by question.

The least frequent strategy used by the respondents have also been identified by the researchers. With an average mean of 3.05 and a median of 3.00, social strategies are least favorable strategies by engineering students in this study. This can be seen at a low mean on item number eleven (11) in the questionnaire with 2.91, where respondents were asked if they would encourage others to correct errors in their speaking. Besides that, the respondents would also avoid trying to talk about unfamiliar topics when being asked in item number ten (10). Apparently, majority respondents responded that this strategy doesn't fit them, and prefer to ask for help from their conversation partner should they want to use any social strategies.

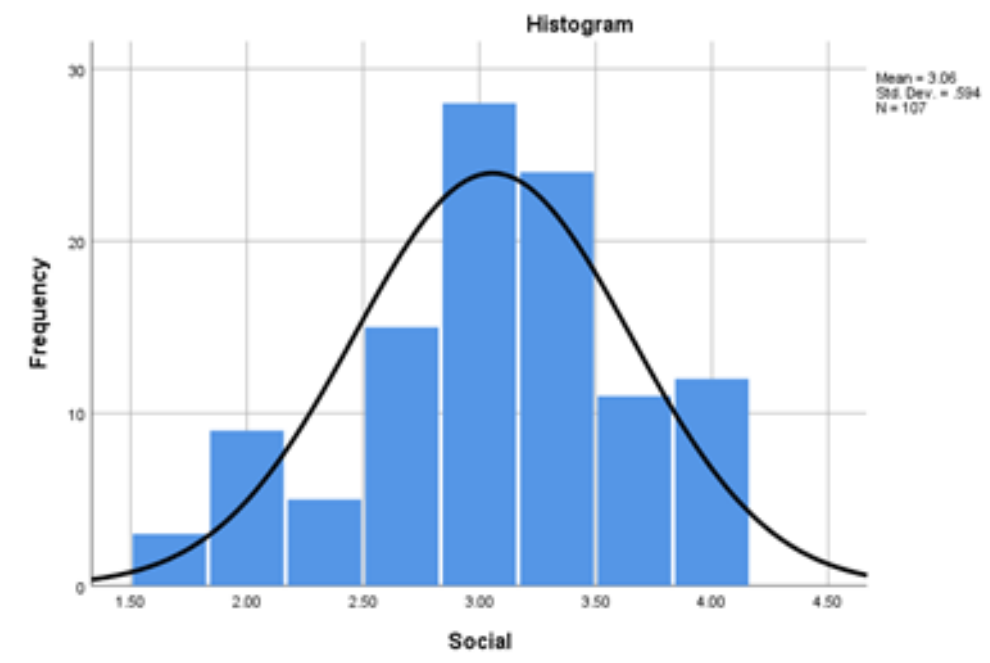

Table 5: Social strategies' normal distribution graph 


\section{Learners' motivation level}

The second research question deals with the learners' motivation level. The 4 Likert scale (Never True, Not True, True, and Always True) was used in the questionnaire to identify the learners' motivation level based on their current practice and experience in learning the second language. The data then being analyzed to see the level of motivation (very low, high, average, low, and very low). Based on the data analysis, it is found out that learners' motivational level of learning English speaking skills are on an average level. This can be seen from the graph below where a mean of 3.01 is recorded representing the learners' motivation level.

\section{Statistics}

\begin{tabular}{llr} 
Motivation & & \\
$\mathrm{N}$ & Valid & 107 \\
\cline { 2 - 3 } & Missing & 0 \\
\cline { 2 - 3 } Mean & & 3.0130 \\
\hline Median & & 3.0000 \\
\hline
\end{tabular}

Table 6: Learners' motivation level

From the study, a total of 60 respondents or $56.1 \%$ out of 107 respondents are having average to a very high motivation level in learning the second language especially in improving their speaking competencies. The remaining 47 respondents are believed to have a low to very low motivation level. Despite having an average motivation level among the respondents, the majority or 98 respondents are most likely to have a high intrinsic motivation. They would not hesitate to ask the other person to slow down or say it again if they do not understand something in second language. They always encourage themselves to speak the second language even when they are afraid of making mistakes. This can be seen from a mean score of 3.21 and 3.23 on the item number eleven (11) and nine (9) in the questionnaire. 


\begin{tabular}{|c|c|c|c|c|}
\hline \multicolumn{5}{|l|}{ Descriptive Statistics } \\
\hline & $\mathrm{N}$ & Mean & $\begin{array}{l}\text { Std. } \\
\text { Deviation }\end{array}$ & Level \\
\hline $\begin{array}{l}\text { Item } 4 \\
\text { I plan my schedule so I will have enough time } \\
\text { to study SL. }\end{array}$ & 104 & 2.75 & .760 & Low \\
\hline $\begin{array}{l}\text { Item } 5 \\
\text { I look for people I can talk to in SL. }\end{array}$ & 107 & 2.93 & .669 & Low \\
\hline $\begin{array}{l}\text { Item } 9 \\
\text { I encourage myself to speak SL even when I } \\
\text { am afraid of making a mistake. }\end{array}$ & 107 & 3.21 & .583 & High \\
\hline $\begin{array}{l}\text { Item } 10 \\
\text { I give myself a reward or treat when I do well } \\
\text { in SL. }\end{array}$ & 107 & 2.82 & .810 & Low \\
\hline $\begin{array}{l}\text { Item } 11 \\
\text { If I do not understand something in SL, I ask } \\
\text { the other person to slow down or say it } \\
\text { again. }\end{array}$ & 107 & 3.23 & .623 & High \\
\hline $\begin{array}{l}\text { Item } 13 \\
\text { I practice SL with other students. }\end{array}$ & 106 & 2.93 & .707 & Low \\
\hline $\begin{array}{l}\text { Item } 14 \\
\text { I ask for help from SL speakers }\end{array}$ & 105 & 2.91 & .774 & Low \\
\hline $\begin{array}{l}\text { Item } 15 \\
\text { I ask questions in SL. }\end{array}$ & 107 & 2.82 & .670 & Low \\
\hline
\end{tabular}

Table 7: High and low mean scores

Besides that, learners' low motivation level contributed greatly by several factors. With a low mean ranging from 2.75 to 2.93 , these learners may have low self-esteem which caused lower motivation level to practicing speaking skills. Low self-esteem can be seen from their hesitation to practice speaking skills with another person either to communicate or to receive feedback. Planning for self-development is in fact, one of the biggest drawbacks which triggered low level of motivation among the learners. Table 7 shows the highest and the lowest mean scores contributing to the level of motivation among the Semester 1 engineering students in a polytechnic in Sarawak.

\section{Discussion}

Learning speaking skills in the second language has been a daunting task, especially to students who are lacking self-confidence and self-esteem (Zakaria et al., 2018). Therefore, a range of strategies may be used by learners to improve their speaking ability. Understanding how learners learn speaking skills is crucial for teachers to come up with new ideas and methods to teach speaking skills more efficiently. The primary purpose of the present study is to determine which language learning strategies are the most preferred by engineering students in a polytechnic in learning speaking skills. Hence, a questionnaire which consisted of 18 items related to LLS in learning speaking skills was adapted and distributed to the respondents to study their most preferred LLS. The questionnaire which was adapted from Cohen et al. (2002) includes several LLS, namely memory strategies, cognitive strategies, compensation strategies, metacognitive strategies, affective strategies, and social strategies. 
Based on the findings of the study, it was found that the engineering students mostly used metacognitive strategies in learning speaking and their least preferred strategy is social strategies.

Metacognitive strategies refer to the act of thinking used by students in managing their own learning which include problem identification, planning and self-evaluation (Oxford, 2002). The findings of the study revealed that the respondents were aware of their own thinking when speaking in the target language. A similar finding was found by Rubaai et al. (2019) whereby learners notice their mistakes when using English language. The majority of the respondents agreed that they planned out in advance about what to say and they would think of how something would be spoken in its native language so that they would be able to speak of it in the same way. A number of studies in the language learning field would agree with the results of this study as metacognitive strategies have been proven useful when used together with other strategies and they allow for maintaining and transferring of strategies across different tasks (O'Malley and Chamot, 1990). A similar study in Indonesia by Syafryadin (2020) also found the same result. The participants in the study were found to prefer organizing and evaluating learning which both are parts of metacognitive strategies.

Another study conducted in Indonesia in studying learners' learning strategies however found that the respondents prefer memory strategies while metacognitive strategies were placed second (Wael et al., 2018). Based on the study, the respondents prefer using auditory as well as visual stimuli in learning speaking as these would help them to improve their memories of the target language. Nonetheless, the respondents of the study also preferred to use metacognitive strategies in learning speaking skills by using dictionary and listing down lexicon to prepare them for speaking activities. In contrast, the respondents of the study also preferred to use social strategies by asking for clarification from knowledgeable others such as their peers or lecturers. Whereas in this study, the respondents did not prefer using social strategies as they would not want to be corrected while speaking as it has become our culture to not correct others as it would be deemed as a bad manner (Noor et al., 2016). The respondents were also reportedly avoiding conversations on unfamiliar topics. This could happen due to a number of reasons including low self-confidence and low self-esteem as the respondents only preferred to ask for help from their conversation partner.

A similar study on the use of LLS among secondary students by Zakaria et al. (2018) also found a contrasting result with this study. Based on the findings, the respondents did not prefer to practice saying something in its native language, perhaps due to the geographical location of the respondents where they had never met a native speaker. Aside from that, the age of the respondents may also become the factor why metacognitive strategies are not popular among secondary school students compared to those in the tertiary level of education.

Learner's ability to speak fluently is much influenced by their level of motivation. As can be seen from the findings of this study, most learners' level of motivation was at the average level. At this level of education after going through 6 years of English language lessons in primary school and 5 years in secondary school, the students should already have some basics in speaking the language. However, due to some factors such as low self-esteem, learners tend to feel insecure when speaking the language.

Different strategies can be applied in motivating learners to learn speaking (Sanjay \& Narayana, 2020). As learner's learning strategies might differ from one another, it is important to identify the most suitable LLS to the learner. By doing so, learners would feel 
more motivated to learn. Therefore, learners should be given the opportunity to practice autonomous learning (Isik \& Balçikanli, 2020). When learners are given autonomy on their learning, they are more interested to learn especially when the materials used in practicing speaking is something that is of their interest (Lai, 2011). With the advancement of technologies nowadays, there are many ways that learners could use in doing self-practice. As mentioned by Rajendran (2019) in a study conducted, online platforms can be a good way to motivate students to learn speaking skills. This will enable language learners to be fluent and motivated in learning. There are many activities that could be carried out online that could encourage learners to communicate in English. Learners would be able to learn at their own pace and this would encourage learners to be an independent language learner.

\section{Conclusion}

Educators and curriculum developers have to emphasize on the importance of language learning strategies used by learners in learning speaking skills to help them deliver a more efficient language lessons. The findings of the study also demonstrate the need for lecturers to work more on building students' motivation aspect to help them engage more actively in managing their own learning. In addition, it stresses the need for educators to create more activities which encourage the use of social strategies as it is an important aspect in polishing students' communicative competence. Moving forward, more studies should be done to study the factors affecting the use of LLS among students for the exact purpose of understanding their way of learning a language. Moreover, it would be more efficient for students to develop their speaking abilities if they are aware of how to use LLS in learning speaking.

Through the comprehensive exploration of this study on language learning strategies, significant insight has been found in understanding the engineering students' learning strategies in learning speaking skills, especially English. Moreover, educators would further look for more effective teaching approaches that could be implemented in the language classroom to compensate for the engineering students' learning styles.

In this regard, this study would give awareness to the higher learning educators on the principle that might affect their teaching context. Through the analysis made by this study, teaching approaches and teaching methods should be aligned to the learners' learning strategies on how the learners learn language especially speaking skills.

In addition to this, the overview presented in this research could also be extended in understanding non-engineering language learners or to further study other language skills such as reading, listening, and writing.

\section{References}

Asif, M., Zhiyong, D., Rasool, S. F. \& Madni, M. A. (2019). Analysis of Motivation Level of L2 Learners in Enhancing Speaking Skill. European Online Journal of Natural and Social Sciences 2019, 8 (3), 584-593.

Bayuong, P. D., Hashim, H. \& Yunus, M. M. (2019). Identifying language learning strategies used by ESL learners in a rural primary school. International Journal of Academic Research in Progressive Education \& Development, 8(3), 151-165. https://doi.org/10.6007/IJARPED/v8-i3/6311

Burns, A., \& Joyce, H. (1997). Teaching Speaking Skills [Unpublished Master's thesis]. National Center for English Language Teaching and Research, Sydney. Retrieved from https://is.muni.cz/th/zmjkc/THESIS_Solcova_text.pdf 
Hapsari, A. (2019). Language Learning Strategies in English Language Learning: A Survey Study. Journal of English Teaching Studies, 1(1), 58-68.

Hardan, A. A. (2013). Language learning strategies: A general overview. Procedia-Social and Behavioral Sciences, 106, 1712-1726. https://doi.org/10.1016/j.sbspro.2013.12.194

Isik, T., \& Balçikanli, C. (2020). EFL Teachers' Autonomy Supportive Practices for Out-of-Class Language Learning. IAFOR Journal of Education: Studies in Education, 8(4), 63-78. https://doi.org/10.22492/ije.8.4.04

Lai, E. R. (2011). Motivation: A literature review. (Research Report). Pearson.

Lee, C. K. (2010). An overview of language learning strategies. Annual Review of Education, Communication \& Language Sciences, 7, 132-152.

Mahmood, S. (2014). Teaching English to engineering students through innovative techniques. Journal of Education and Practice, 5(8), 192-197.

Noor, Z. A. M., Yusoff, N. M. R. N., Yasim, I. M. M., \& Kamarudin, M. Y. (2016). Foreign Language Vocabulary Learning Strategies in Malaysia. Creative Education, 7(03). 428. https://doi.org/10.4236/ce.2016.73042

O'Malley, J. M., \& Chamot, A. U. (1990). Learning Strategies in Second Language Acquisition. Cambridge: Cambridge University Press.

https://doi.org/10.1017/CBO9781139524490

Oxford, R. (2002). Language learning strategies. In R. Carter and D. Nunan (Eds.), The Cambridge guide to teaching English to speakers of other languages (pp. 166-172). Cambridge: Cambridge University Press.

Oxford, R. L. (1990). Language learning strategies: What every teacher should know. New York: Newbury House/Harper \& Row.

Park, G. P. (2011). The Validation Process of the SILL: A Confirmatory Factor Analysis. Canadian Center of Science and Education, 4(4), 21-27. http://dx.doi.org/10.5539/elt.v4n4p21

Rahimi, M., Riazi, A., \& Saif, S. (2008). An investigation into the factors affecting the use of language learning strategies by Persian EFL learners. Canadian Journal of Applied Linguistics, 11(2), 31-60.

Rajendran, T., Naaim, A. N., \& Yunus, M. M. (2019). Pupils' Motivation and Perceptions Towards Learning English Using Quizvaganza. International Journal of Scientific and Research Publications, 9(1), 1-9. http://dx.doi.org/10.29322/IJSRP.9.01.2019.p8529

Rao, P.S. (2019). The Importance of Speaking Skills in English Classrooms. Alford Council of International English \& Literature Journal (ACIELJ), 2(2), 6-18.

Rubaai, N., Hashim, H., \& Yunus, M. M. (2019). Identifying English Language Learning Strategies Used by Polytechnic Students. Religación, 4, 98-103.

Rubin, J. (1987). Learner strategies: Theoretical assumptions, research history and typology. In A. L. Wenden \& J. Rubin (Eds.), Learner strategies in language learning, 15-30. Englewood Cliffs, NJ: Prentice-Hall.

Sanjay, G., \& Narayana, T. (2020). Teaching speaking skills through motivational strategies. Research Journal of English (RJOE), 5(5), 37-49.

Shiamaa, A. E. F. T. (2006). The effectiveness of a task-based instruction program in developing the English language speaking skills of secondary stage students. (Doctoral dissertation, Ain Shams University). Retrieved from https://files.eric.ed.gov/fulltext/ED523922.pdf

Shrestha, R. N., Pahari, B. R., \& Awasthi, J. R. (2016). The Importance of English in Engineering for Professional Communication: A Study of Nepalese Context. Journal of the Institute of Engineering, 12(1), 222-227. 
Syafryadin. (2020). Students' Strategies in Learning Speaking: Experience of Two Indonesian Schools. Vision: Journal for Language and Foreign Language Learning, 9(1), 34-37. https://doi.org/10.21580/vjv9i14791

Tigarajan, D., Yunus, M. M., \& Aziz, A. A. (2016). What good language learners do to learn English language. Journal of Education and Social Science, 5(2), 132-145.

Vrettou, A. (2014). The "Very Successful L2 Learner" In the Sixth Grade of The Greek Elementary School as Portrayed Through a Qualitative Study. Multilingual Academic Journal of Education and Social Sciences. 2(2), 1-15.

Wael, A., Asnur, M. N. A., \& Ibrahim, I. (2018). Exploring Students' Learning Strategies in Speaking Performance. International Journal of Language Education, 2(1), 65-71. https://doi.org/10.26858/ijole.v2i1.5238

Wenden, A. L. (1987a). Conceptual background and utility. In A. L. Wenden \& J. Rubin (Eds.), Learner strategies in language learning, 3-13. Englewood Cliffs, NJ: Prentice-Hall.

Zakaria, N. Y. K., Zakaria, S. N., \& Azmi, N. E. (2018). Language Learning Strategies Used by Secondary School Students in Enhancing Speaking Skills. Creative Education, 9, 23572366. https://doi.org/10.4236/ce.2018.914176

Zare, P. (2012). Language learning strategies among EFL/ESL learners: A Review of Literature. International journal of humanities and Social Science, 2(5), 162-169. 